\title{
Determining and Analyzing Corrosion Potential of Groundwater in Ghorveh Through Simulating Corrosion Indices
}

\author{
Soraya Movahhed ${ }^{* 1}$, Roshanak Rezaei Kalantari ${ }^{2,3}$, Mostafa Khezri ${ }^{4}$, Ali Azari ${ }^{5}$ \\ 1. M.Sc. Student, Environmental Engineering, Islamic Azad University, Science and Research Unit, \\ Tehran, Iran \\ 2. Professor, Department of Environmental Health Engineering, School of Public Health, \\ Iran University of Medical Sciences, Tehran, Iran \\ 3. Research Center for Environmental Health Technology, Iran University of Medical Sciences, \\ Tehran, Iran \\ 4. Associate professor, School of Environmental Engineering, Islamic Azad University, \\ Science and Research Unit, Tehran, Iran \\ 5. PhD student in Environmental Health, School of Public Health, Tehran University of Medical \\ Sciences, Tehran, Iran \\ *E-mail: enviromentalh@yahoo.com
}

Received: 28 Jan 2017 ; $\quad$ Accepted: 8 May 2017

\begin{abstract}
Background and Objective: Scaling and corrosion are factors that cause loss of drinking water quality. They create problems for public health, reduce water quality, and decrease useful life of plumbing equipment. Therefore, their control substantially influences public health and water quality. Consequently, the present research intended to study corrosion or scaling indices of groundwater resources in Ghorveh County in Kurdistan Province using the Monte Carlo statistical method in order to reduce uncertainty and increase accuracy in estimating the values of the indices.

Materials and Methods: Sixty four samples from 16 wells supplying water for Ghorveh County were taken during a 12- month period in 2012-2013 in order to study the qualitative characteristics of water and identify the corrosion and scaling potential of the water in the region using the Langelier, Ryznar, Larson-Skold, and Puckorius indices.

Results: The mean values for the Langelier, Ryznar, Puckorius, and Larson-Skold indices were $0.5449 \pm 0.015,6.8878 \pm 0.017,7.3754 \pm 0.0078$, and $0.0919 \pm 0.0390$, respectively. Moreover, the estimated probabilities for the occurrence of corrosion and scaling phenomena were $6.59 \%$ and $47.57 \%$ for the Langelier index, less than $11.77 \%$ and $54.33 \%$ for the Ryznar index, less than $17.47 \%$ and $36.33 \%$ for the Puckorius index, and $0.15 \%$ and $99.74 \%$ for the Larson-Skold index.

Conclusions All of the studied indices yielded identical results for the water status: they indicated a relatively high scaling potential of the water in the region. Based on Pearson's test, the most important factors influencing the values of the studied indices were $\mathrm{pH}$ and concentration of calcium ions.
\end{abstract}

Keywords: Corrosion indices of Water, Monte Carlo Simulation, Groundwater, Ghorveh County 


\title{
تحليل و بررسى يتانسيل خورند زى آبهاى زيرزمينى شهرستان قروه از طريق شبيهسازى شاخص هاى خورند
}

\author{
ثريا موحد'":، روشنك رضايى كلانترى"ז"، مصطفى خضرى"، على آذرى" \\ دانشجوى كارشناسى ارشد مهندسى محيطزيست، دانشگاه آزاد اسلامى واحد علوم تحقيقات تهران، تهران، ايران

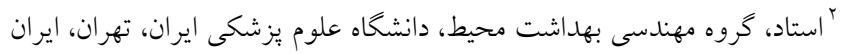

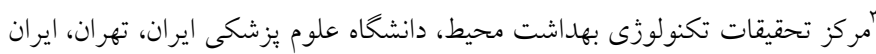

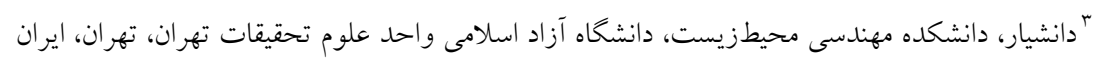

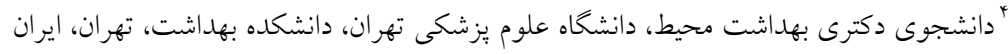

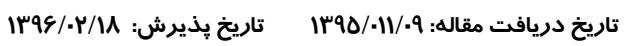

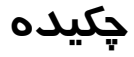

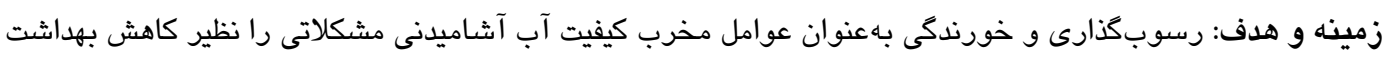

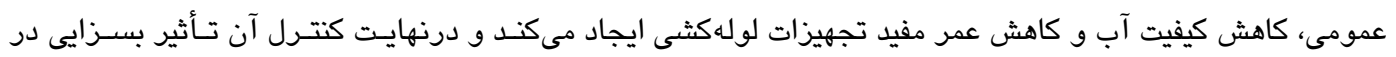

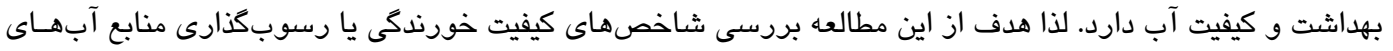

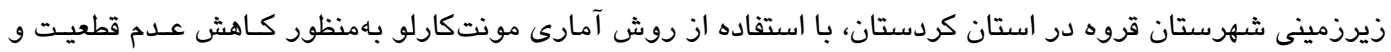

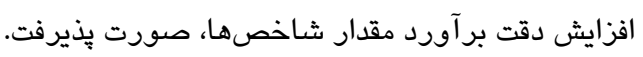

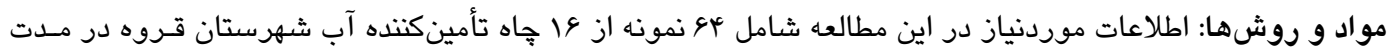

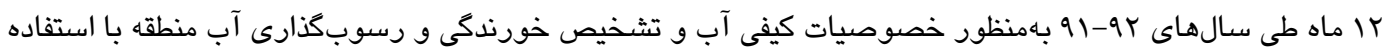

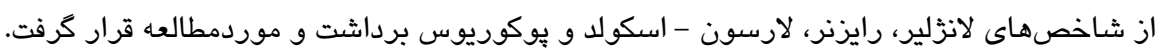

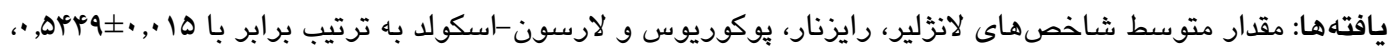

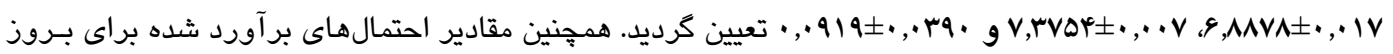

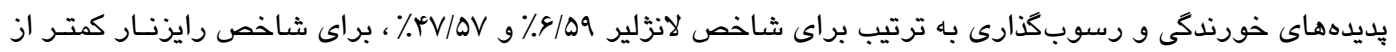

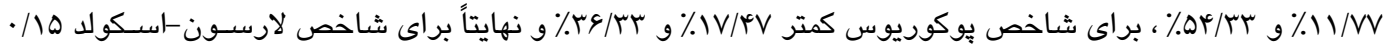

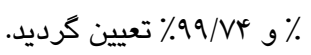

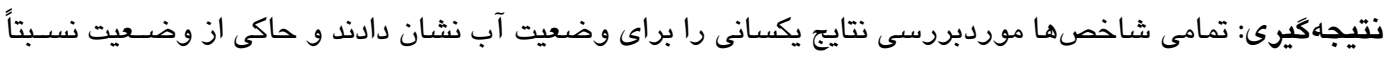

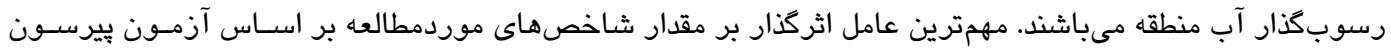
pH

كلمات كليدى: شاخصهاى خورندكى آبششبيهازى مونت- كارلو ، آبهاى زيرزمينى شهرستان قروه 
فرآيندى است كه در آن كاتيونهاى دو ظرفيتى مانند كلسـيم و

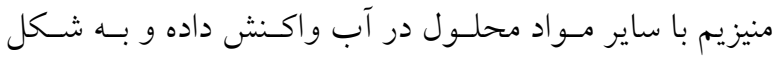
لايهاى در جداره داخلى لوله تهنشين مىشوند. هُ متداولتسرين

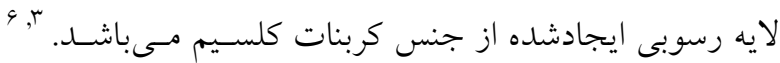
فرايند رسوبكَارى سبب مشكلاتى مانـــ كرفتكى لولـهــا

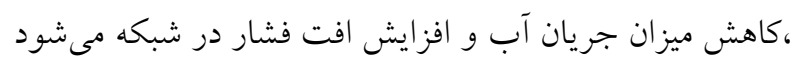
كه اين امر نيز افزايش هزينه بهرهبردارى تأسيسـات آبسى را بــهـ

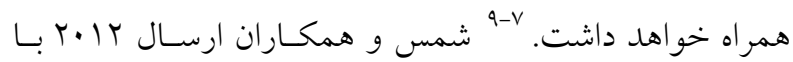
بررسى خوردگى و رسوب كذارى آب در شبكههاى آبرسانى روستايى طبس كزارش نمودنـــــــه آب در ايـن شهـه داراى خاصيت خورندگى بوده است و علـت اصسلى آن را مسى تـوان

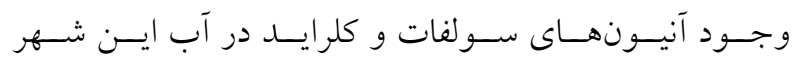
دانست. "ل ليونتان و همكاران در سال ب ب.ب در مطالعهاى در

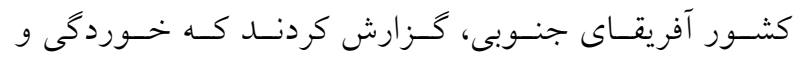

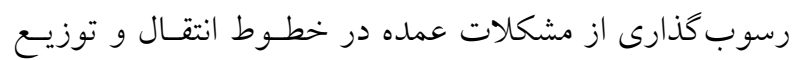
آبهاى زيرزمينى است و مكانيزم اثر و شــت آن بـهـ كيفيـت

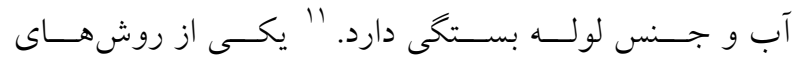

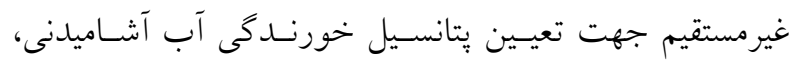
انديسهاى خورندگى هستند. اين انديسها بيانكر خصوصيات

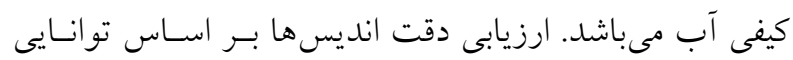

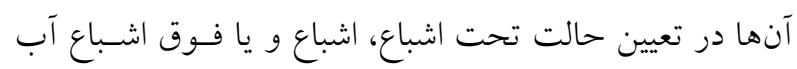
برحسب كربنات كلسـيم و نيـز بيشـحويى ظرفيـت آبهـا در ذخيرهسازى و يا ايجاد رسوب كربنـات كلسـيم مسىباشـد. در حال حاضر كاربرد شاخصهاى خورنـدكى ازجملـه رايزنـر و

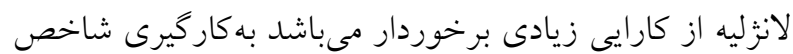
لانزليه بهتنهايى و بهطور مستقل جهت بايش و تعيين بِّانسيل خورندگى آب آشاميدنى شهر مناسب نيست و همواره نتايج را

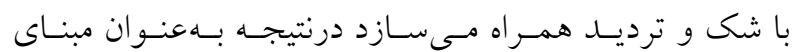

\section{مقدمه} حيات موجودات و سلامتى انسانها بيش از هـر خيـز بـهـ

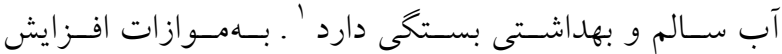

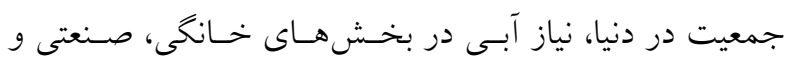
كشاورزى نيز به شكل قابل توجهى افزايشيافتـه كـه ايـن امـر

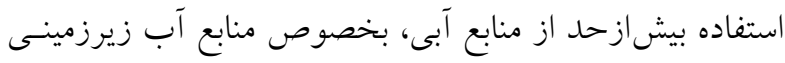

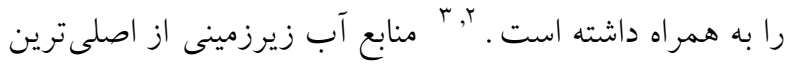

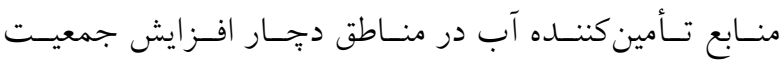
به حساب مى آيند به گونهاى كه در بسـيارى از كشـورهاى دنيـا

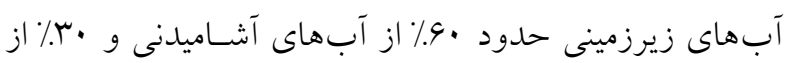
آبهاى بخش كشاورزى را به خـود اختصـاص دادهانـــ ايسن منابع آبى محدود بوده وازديد انسانها ينهان مى باشند اين امـر سبب افزايش غير محسـوس آلـودكى در آب زيرزمينسى شـده

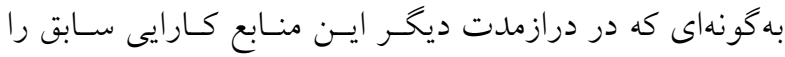

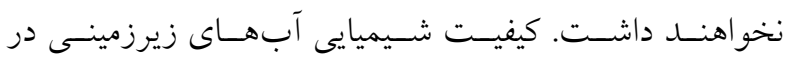

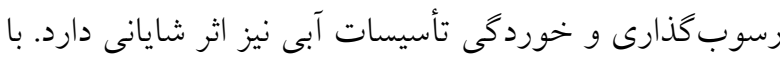
توجه به اهميت اين منابع و با در نظر كرفتن اين موضسوع كـهـ كشور ما جزء مناطق خشك و نيمهخشى طبقهبندى مىشود،

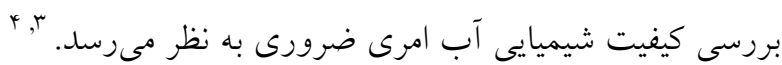
ايران بهخصوص در دو دهل كذشته كه در مرحله توسعه علمى و اقتصادى است، اين مسائل بهعنوان يكى رقابت اقتصادى بــه وجود آمده است. دركذشته همه تحقيقـات بـر روى نشـت و خسارت اقتصادى حاصل از خورندگى متمركزشده است، امـا در حال حاضر جنبههاى بهداشتى و زيباشناختى كيفيت بيشـتر

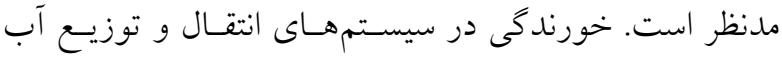

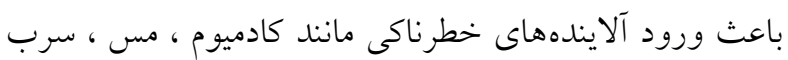

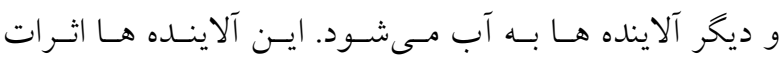

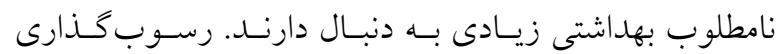


تحليل و بررسى يتانسيل خورندكى آبهاى زيرزمينى شهرستان قروه از طريق شبيهسازى شاخصهاى خورندكى به روش مونت-كارلو

دليل ميزان بارندگى بايين و خشكسالىهاى اخير و همجنــين ضرورت يايش سـاليانه منـابع آب زيرزمينسى ازنظـر يتانسـيل خورندگى، به شمار مى آيند. هدف از اين مطالعه، آناليز فيزيكى و شيميايى و بررسى خورنده يا رسوبكَذار بـودن منـابع آب شهرستان قروه با توجه شاخص هاى لانزليه، رايزنز، لارسـون اسكولد، يوكوريوس و استفاده از روش تحليلى آمارى مونتكارلو شبيه سازىشده و مقايسـهـ بـا مقـادير آسـتانه خــوردگى مىباشد. در اين مطالعه با استفاده از اطلاعات كيفيت شيميايى 19 حلقه آب جــاه شهرسـتان قـروه بـا مقــادير شـاخصهــاى خورندگى نشان داد كه آب جاه تمايل رسوب گذارى كربنـات كلسيم مىباشند.

\section{مواد و روشها}

اين مطالعه از نوع توصيفى - مقطعى است . در اين مطالعه تعداد 19 جاهاه تأمين كننده آب شهرستان قروه طى با ماه ازنظر شاخص هاى فيزيكسى و شـيميايى موردبررسىى و آنـاليز قـرار كرفتند. براى نمونهبردارى از ظروف يلاستيكى با حجم نيم ليتر استفاده شد. يس از برداشت نمونهها و انتقال سـريع آنهـا بــه آزمايشخاه مركزى شـركت آب و فاضـلاب اسـتان كردسـتان،

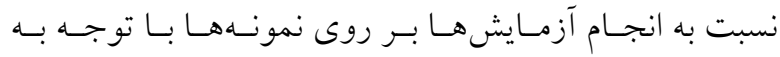
يارامترهاى موردنظر اقــام گرديــد. يُار امترهـاى pH و دمـا در محل نمونهبردارى و به ترتيب بـه وسـيلهpH سـنج و دماسـنج انــازهذيـرى شـــ. مقــادير سـختى كلسـيم، قليـائىات،كلـر باقيمانــه، كل جامــات نـامحلول، كـاتيونهــا و آنيـونهـا در آزمايشگاه و با استفاده از استاندارد سه • ا سنجش شدند 'ا'، در ادامه شـاخص هـاى لانزليـه (Langelier Saturation Index)، رايزنـــ (Ryzner Saturation Index)، لارسـون اسـكولد ويوكوريوس (Larson-Skold Index)
تصميم گيرى قابل استفاده نيست مخر اين كه با سـاير روشهـا بهور همزمان به كار گرفته شود. شاخص اشباع لانزليه (LSI) مدلى است كه درجـه اشـباع

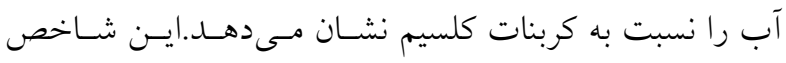
مفهوم اشباع را با استغاده از pH بهعنوان يكى متغير اصلى بيـان مى كند. در تعريف ديخر LSI بهعنوان تغيير pH جهت رسيدن آب به تعادل مطرح مىشود. rا' شاخص بِيدارى رايزنر (RSI) ارتباط بين حالت اشباع كربنـات كلسـيم و تشـكيل يوسـته را

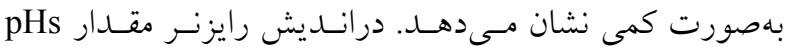
بهوسيله pH واقعى، غلظت يـونهــاى كلسـيم، بيكربنات،كـل

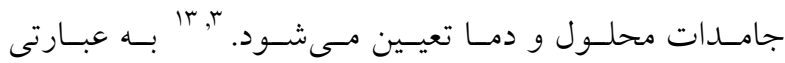
شاخص هاى لانزليه و رايزنر تفاوت بين pH واقعى آب و pH

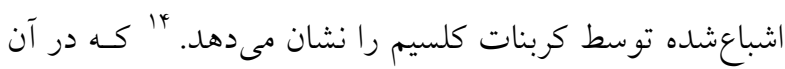
يعنى pH رابطه (1)

كلسيم ضريب -ضريب قليائيت - ضريب TDS انديس لارسون - اسكولد بهمنظور بررسى خورنسـده بـودن آب در مجاورت با لولههاى فـولادى ولولـههـاى فـولادى بـاــا ساختار كربنى سبك ولولههاى جانى را نشان مى دهد. انديس يوركوريوس بر اساس ظرفيت بافرى آب بوده و حداكثر مقدار رسوبى كه جهت ايجاد تعادل در آب مىتواند تشكيل شـود را بيان مى كند. انديس فـوق بـهـهـورت تجربسى بـوده و مقـادير عددى بـهدسـت آمــده از ايسن رابطـه همانتـد انـديس رايزنـر مىباشند. "19ا در نظر كرفتن شرايط جغرافيـايى دشـت قـروه يكى از دشتهاى بسيار مهم استان كردستان بـه لحـاظ تــأمين آب شرب و صـنعتى و كشـاورزى منطقـه و همجنـين وجـود منابع آب زيرزمينى، محسوب مى گردد و كنترل كيفى اين منابع آب زيرزمينى امرى لازم و ضرورى مسىباشـد و از طرفى بـهـ 
بالاتر اسـت يـا كمتـــ ) و آزمــون اندرسـون- دارلينـخ بـراى بررسى ميزان انطباق خوب توابع تراكمى استفاده شد.

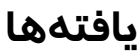

شهرستان قروه -وسعتى در حدود ... WN كيلومترمربع از كل استان كردستان را در بركرفته است. آبوهواى قروه نسبستاً سرد و نيمه خشك است و ميـزان بارنــدى در ايـن شهرسـتان سالانه بهطور متوسط در حدود •^ץ ميلىمتر باشد. بـه همسين علت آب هاى زيرزمينى عمده ترين منابع تـأمين كنـــده آب در

$$
\text { اين بخشها به شمار مى آيد. }
$$

به همين منظور بررسى ميزان بايدارى و كيفيـت آبهـاى

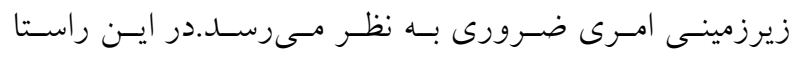
يارامترهاى دخيل در خوردگى و رسوبكَارى سنجش گرديد كه نتايج اين سنجشها در جدول شماره بَ ارائهشده است.
كمك جدول ا محاسبه كرديد و بــر مبنـاى اعـداد حاصـله و

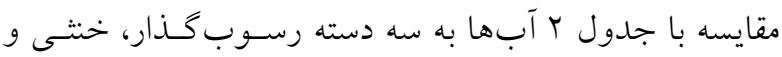
خورنده تقسيم شد. در ادامه بهمنظور مطالعه دقيـق ميـزان بِيــارى جـــهـاى موردمطالعه از روش مونت كارلو اسـتفاده شــــ. روش مونــــ-

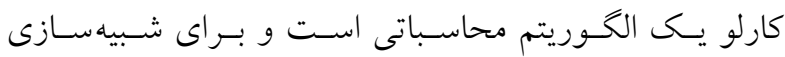

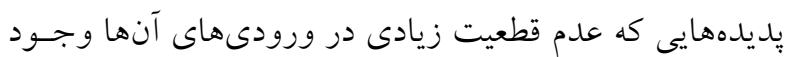
دارد مفيد مىباشد. بهمنظور محاسبه نتايج، نمونه هـا بـه روش تصادفى از خاههاى موردمطالعه اندازهيرى شد. نحوه استفاده

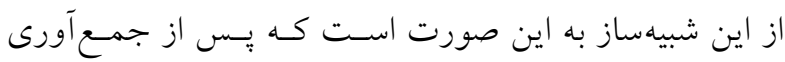

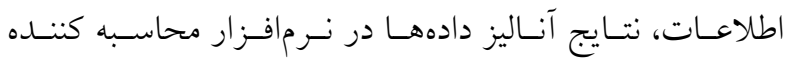
شاخص هاى خورندگى وارد و تعيين خواهد شد. 19 در نهايت از روشهاى آمارى Single T-test جهت تفسير ميانخين انديسها (يا بهعبارتديخـــ تعيسين ايسن موضسوع كـهـ مقدار متوسط هر شـاخص در جامعـه آمـارى از حسـ آستانه

جدول ا: معادلات مربوط به شاخصهاى پايدارى

\begin{tabular}{|c|c|}
\hline شاخص هاى يايدارى & معادله مربوط به شاخصها \\
\hline ل انززلير & $\mathrm{LI}=\mathrm{pH}-\mathrm{PH}_{\mathrm{s}}$ \\
\hline رايزنر & $\mathrm{RI}=2 \mathrm{pH}_{\mathrm{s}}-\mathrm{pH}$ \\
\hline ل ارسون-اسكولد & $\mathrm{LS}=\left(\mathrm{C}_{\left(\mathrm{Cl}^{-}\right)}+\mathrm{C}_{\left(\mathrm{SO}_{4}^{2-}\right)}\right)\left(\mathrm{C}_{\left(\mathrm{HCO}_{3}^{-}\right)}+\mathrm{C}_{\left(\mathrm{CO}_{3}^{2-}\right)}\right)^{-1}$ \\
\hline يوكوريوس & $\begin{array}{c}\mathrm{pH}_{\mathrm{eq}}=1 / 465 \log (\mathrm{T} \text { Alkaliniti })+4 / 54 \\
\mathrm{PI}=2 \mathrm{pH}_{\mathrm{s}}-\mathrm{pH}_{\mathrm{eq}}\end{array}$ \\
\hline
\end{tabular}

جدول r: تقسيمبندى آب بر اساس شاخصهاى پايدارى ^

\begin{tabular}{|c|c|c|c|}
\hline & رسوبگذار & خنثى & خوردندِ \\
\hline LSI & $\mathrm{LSI}>0$ & $0=\mathrm{LSI}$ & $0<\mathrm{LSI}$ \\
\hline RSI & $\mathrm{RSI}<6$ & $6<\mathrm{RSI}<7$ & $\mathrm{RSI}>7$ \\
\hline LSI & $\mathrm{LS}>1.2$ & $0.8<\mathrm{LS}<1.2$ & LS $<0.8$ \\
\hline PSI & $\mathrm{PSI}<6$ & $6=\mathrm{PSI}$ & PSI $>6$ \\
\hline
\end{tabular}



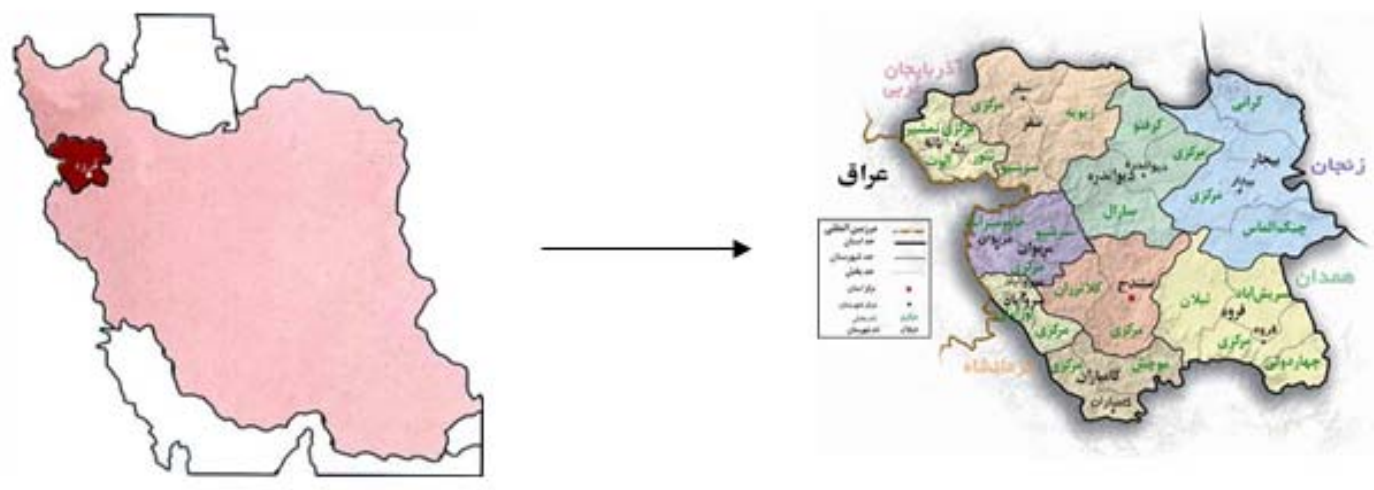

جدول سا: ميانخين بار امترهاى اندازهيرى شده در شهرستان قروه طى با ماه

\begin{tabular}{|c|c|c|c|c|c|c|c|c|}
\hline \multicolumn{8}{|c|}{ عوامل فيزيكى -شيميايى } & \multirow{2}{*}{ 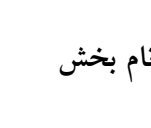 } \\
\hline قليائىات & سختى كلسيم & سختى دائم & سختى كل & TDS & $\mathrm{pH}$ & كدورت & رنگ & \\
\hline $\mid F \Delta / F A$ & YNI/ro & $r M I / Y \Lambda$ & $|O F / F|$ & $9 \wedge \Delta / \cdot \cdot$ & $V / V r$ & $\cdot / Y V$ & ندارد & فصل بهار \\
\hline $199 / \cdot V$ & $r Y Y / F V$ & $\mid \cdot Y / Y 1$ & $191 / 49$ & $V 1 F / 19$ & V/Vq & $\cdot / \mathrm{M}$ & 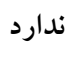 & فصل تابستان \\
\hline PVD/G & $r \cdot 1 / l v$ & $19 Y / 9$ & $1 V V / 91$ & $\forall \wedge \& / \varphi \uparrow$ & V/AY & $\cdot / 41$ & ندارد & فصل پياييز \\
\hline INr/V & $r \Delta I / Y \Lambda$ & IrF & $101 / \cdot 9$ & $0.1 / 91$ & $V / g r$ & $\cdot / Y V$ & ندارد & فصل زمستان \\
\hline
\end{tabular}

جدول ع: ميانخين، كاتيونها و آنيونهاى اندازهيرى شده در شهرستان قروه طى rا ماه

\begin{tabular}{|c|c|c|c|c|c|c|c|c|c|c|c|}
\hline \multicolumn{6}{|c|}{ آنيونها } & \multicolumn{5}{|c|}{ كاتيونها } & \multirow{2}{*}{ نام بخش } \\
\hline فسفات & بى كربنات & كربنات & سولفات & كلرور & فلورايد & آمونياك & يتاسيم & سديم & منيزيم & كلسيم & \\
\hline$\cdot / T r$ & $T Y Y / g T$ & . & 41 & $11 / \cdot 1$ &.$/ 91$ & . & $1 / .9$ & 19 & $19 / 9 \mathrm{~V}$ & $99 / 11$ & فصل بهار \\
\hline$\cdot / 19$ & $r \wedge 9 / 99$ & . & $19 / 90$ & $1 \pi / 0$ & $\cdot / / q$ & . & $\cdot 10$ & $1 \cdot / 1$ & $11 / \cdot r$ & $V V / A$ & فصل تابستان \\
\hline.$/ \cdot 1$ & TVI/gT & . & $M Y / V$. & 19 &.$/ 90$ & . & $1 / \cdot$ & $I V / T$ & $N / r$ & $r q / 0$ & فصل باييز \\
\hline . & $r 94 / \cdot 1$ & . & $\mu_{\Lambda}$ & If &.$/ 90$ & . & $1 / 4$. & $M / r$ & $M / \cdot r$ & $V V / r$ & فصل زمستان \\
\hline
\end{tabular}


همانطور كه در جدول فوق ديده مىشود بر اساس تمامى

شـاخصهــاى موردمطالعـه آب منطقـهـ ازنظـر خورنسدىى يـا

رسوبكذارى در وضعيتى است كـه در مـورد شـاخص هـاى

لانزلير، رايزنار و لارسـون-اسـكولد بـا بيشـترين احتمـال بــه

رسوبكذارى تمايل دارد. ازايسنرو بـر اسـاس شـاخصهـاى

لانزلير، رايزنار و بوكوريوس و لارسون- اسكولد به ترتيب بـاـ

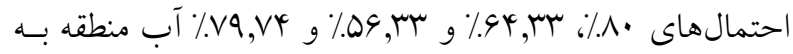

رسوب گذارى متمايل اسـت. ايسن مسـئله در مـورد شـاخص

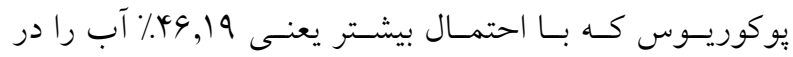
وضـعيت تعـادل مسى دانــد انطبـاق دارد. ازايسنرو آب منطقـهـ موردمطالعه رسوب گذار مىباشد.

سيس با توجه بـهـ مقـادير منــدرج در جــدول شـماره مَ و محاسبات انجامشده، بر اساس روابط لاتزلير ،رايزنر، لارسوناسكولد و بوكوريوس وضعيت آبهاى زيرزمينى در شهرستان قروه تعيين گرديد. در جدول شماره †ا نيز وضعيت كاتيونها و آنيونهاى شهر ستان قروه ذكرشده است.

با توجه به اين موضوع كه آبهـاى زيرزمينى شهرسـان قروه تـــين كنــده آب شـرب و صــنتى و كشـاورزى منطقـه مىباشند يس بررسى اين منابع ازلحاظ بهداشتى حائز اهميـت خواهد بود. نتايج وضعيت آبهاى زيرزمينى شهرستان قـروه، ازنظر تمايل به خورندگى و رسوبكذارى كه بر اساس روش شبيهسازى مونت كارلو برآورد گرديد، ارائهشده است.

جدول 0: خلاصه نتايج بررسى شاخص هاى خورندگى با استفاده از روش مونتكارلو

\begin{tabular}{|c|c|c|c|c|}
\hline احتمال رسوب گذارى & وضعيت تعادل & 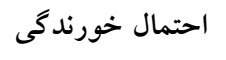 & ميانگين نتايج با حدود اطمينان 90٪ & شاخص خورندگى \\
\hline$\%(V / \mu)$ & $r$. & $\% .9 / 09$ & $\cdot / 0 Y 90-\cdot / 09 \cdot r$ & LI \\
\hline$\%$ \% /OQ & $\%$ \% & $\% 11 / \mathrm{VV}$ & $\Delta / \Lambda V \cdot r-\Delta / Q \cdot \Delta \Delta$ & RI \\
\hline$\% \notin 1 / \wedge \varphi$ & $\% \Psi r / 9 V$ & $\% I V / A V$ & Q/rGVG-Q/rNKT & PSI \\
\hline$\%$ / Q/DQ & $\% \cdot r \cdot / 4$ & $\% 10$ & $|/ T \Delta| \Lambda-1 / T 1 \cdot r$ & LSI \\
\hline
\end{tabular}

جدول \&: همبستخى بين مقادير شاخصهاى خورندگى و مشخصات كيفى آب

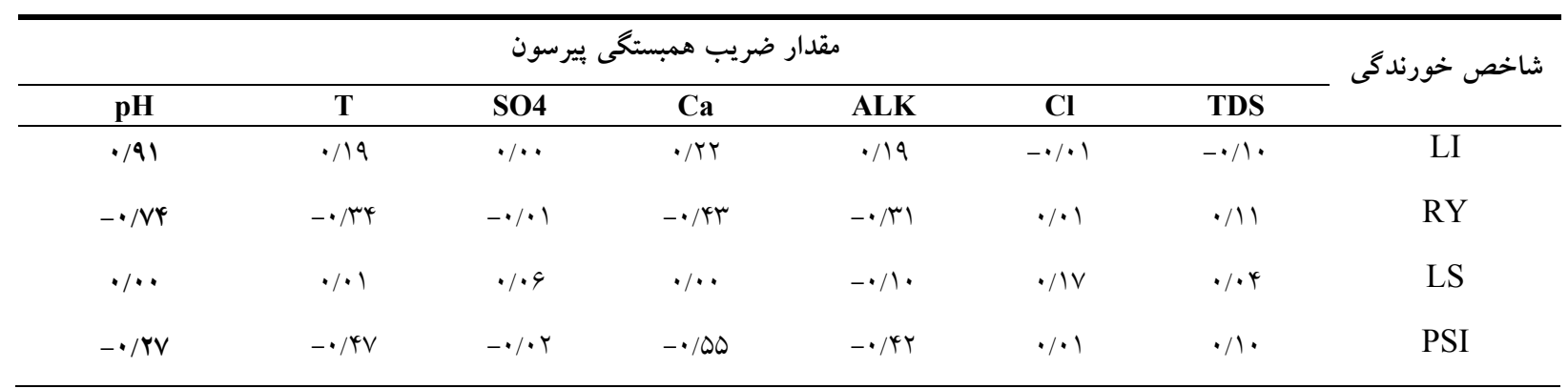


تحليل و بررسى بتانسيل خورندكى آبهاى زيرزمينى شهرستان قروه از طريق شبيهسازى شاخصهاى خورندكى به روش مونت-كارلو

رسوبك كذارى رسيده است كه نشـاندهنــده تـأثير صسنايع بـر كيفيت آب زيرزمينى منطقه است. بوسى رسيده

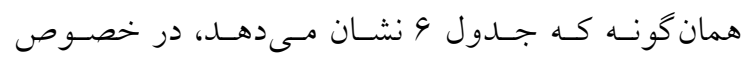
شاخص لانزلير ، ابتدا pH و سبس كلسيم بيشـترين اثـر را بـر روى اين انديس دارند ، يعنى با افزايش pH ، و كلسيم ميـزان شاخص لانزلير افزايش خواهد يافت. كـه ايسن مـورد دربـاره شاخص رايزنر كاملاً برعكس مىباشد يعنى pH كمترين اثر را دارد. به همين خاطر جون كيفيت آب موردمطالعهـ بـر اسـاس نتايج قبل رسوبكَذار مىباشد لذا مىبايستى تمهيـاتى اتخـاذ شود كه آب ازنظر كيفيت به سمت شرايط تعادلى سـوق بيــدا كند. جون به لحاظ اجرائى و عملياتى تغيير pH و يا تنظيم آن

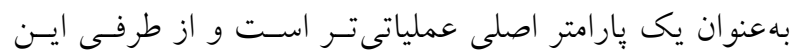

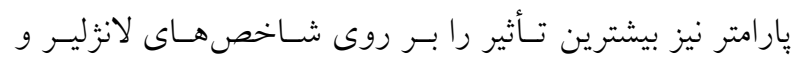
رايزنار دارد ازاينرو بايستى بــا كـاهش مقــدار pH آب مقــدار شاخص لانزلير را كاهش و مقدار شاخص رايزنسار را افـزايش داد تا آب در وضعيت مطلوب قرار گيرد. در مورد نتايجى كـه از شاخص لارسون-اسكولد به دست آمد مستــوان ايـن كونسه توضيح داد كـه ايسن شـاخص در مـورد آبههـيى كـه مقــدار آنيونهاى سولفات و كلرور بــالا اسـت اهميـت بيشـترى دارد زيرا اين آنيونها مىتوانند سيستم تعادل كربناتِ را مختل كرده و از تشكيل رسوب محافظ جلو گيرى كنند. در مورد منابع آب رئب موردمطالعه در اين تحقيق آنيـونهـاى سـولفات و كلـرور در محدوده استانداردهاى تعيينشده توسط ترجمـانهـاى ذيـربط قرار دارد، به همين منظـور ايسن شـاخص تـأثيرى بـر فراينـا رسوبكذارى ندارند. بالينوجود يارامتر قلياييـت يـى رابطـه

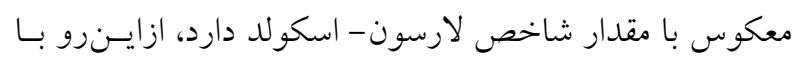

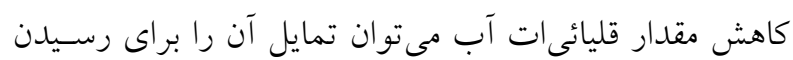

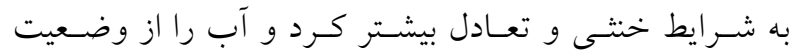

همانطور از نتايج اين مطالعه برمى آيد خوشبختانه تمـامى

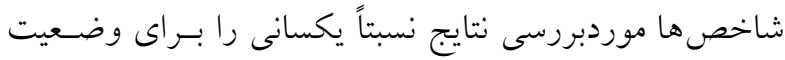
آب بيشبينى كردند. همرتينين بـر اسـاس شـاخص لارسـون-

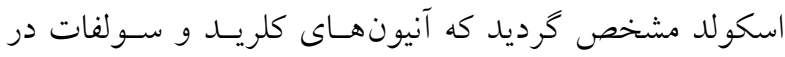
تشكيل فيلم محافظ كربناتِ كه بهعنوان لايه محافظ در مقابـل

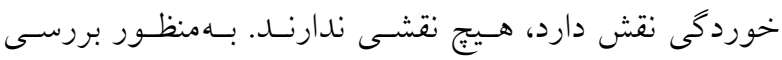

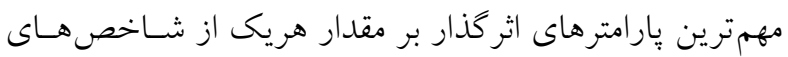
خورندكى مفــار ضـريب همبسـتخى بيرسـون بــاى روابـط همبستكى بين هر يكى از شاخصىهاى خورندكى با بارامترهاى

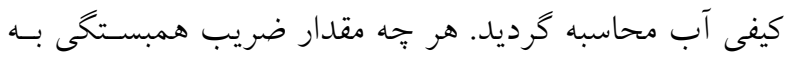
يك نزديكتر باشد نشاندهنده وجود ارتبـاط بيشـتر بـين هـر

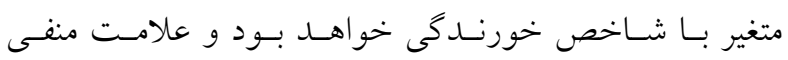
نشاندهنده رابطه معكوس هر يك از يارامترهاى موردمطالعه با شاخصهاى پايدارى آب مىباشد.

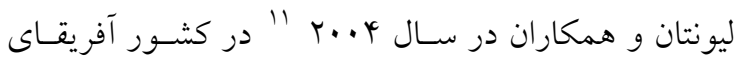

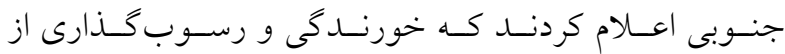
مشكلات متداول در خطوط انتقال و توزيع آبهاى زيرزمينى است و مكانيزم اثر و شدت آن به دو عامل يكى كيفيت آب و ديخرى جنس لولـه بسـتخى دارد. صـرفنظـر از عوامـل ايـن مشكل، راهحل آن تنظيم pH، غلظت كربنات كلسـيم و تثبيـت آب مىباشد. در مطالعهاى كه در سال ع بـا توسط حميدرضـا يور زمانى بهمنظور تعيين بتانسيل خورندىى در آب زيرزمينس

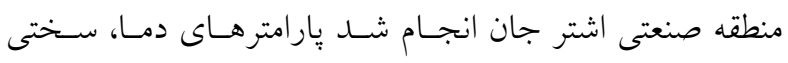
كلسيم، قليائىات، TDS و pH در هـ محل نمونسهبــردارى و در هo أمونه موردسنجش قرار كرفت مقايسه نتايج بهدست آمده نشان داد كه آب زيرزمينى منطقه صنعتى اشـتر جـان در ابتـدا

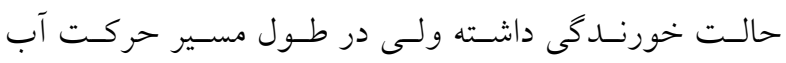
زيرزمينى خاصيت خورندكى آن كم شده و تقريباً بـه شـرايط 


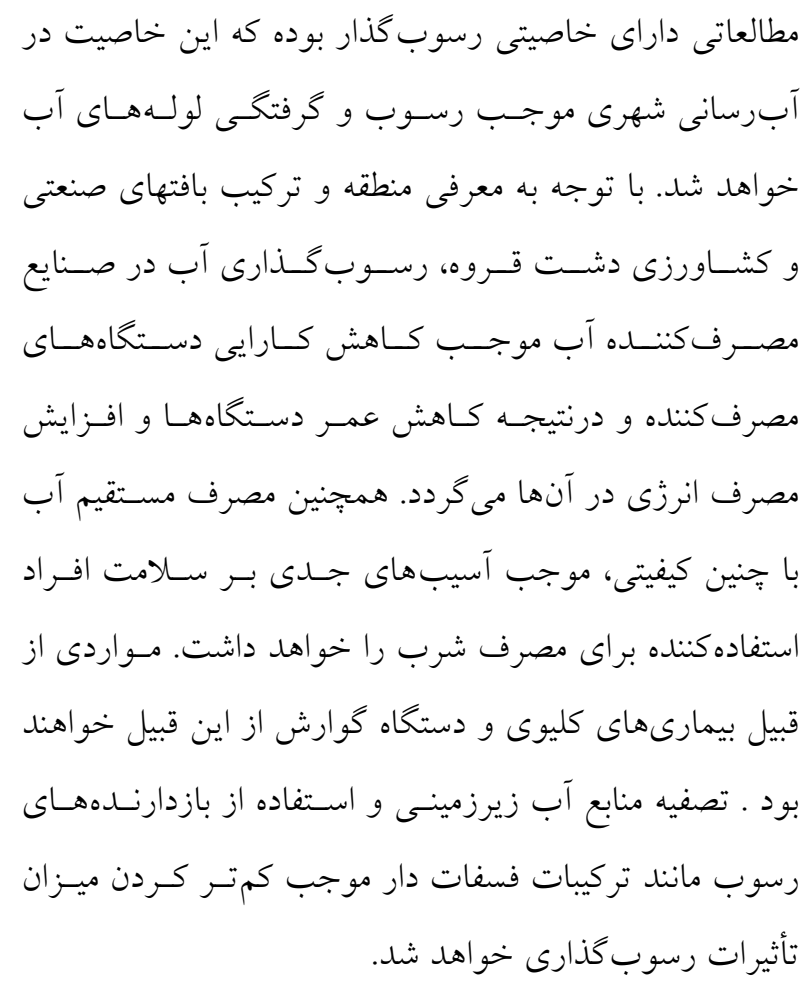

\section{References}

1. Dehghani MH, Ghaderpoori M, Fazlzadeh $M$, Golmohamadi S. Survey of bacteriological quality of the drinking water in rural areas of saqqez city. Iran J Health Environ 2009;2(2): 132-9 [In persian].

2. Heydari M, Bidgoli H. Chemical analysis of drinking water of Kashan district, central Iran. World Appl Sci J 2012;16(6): 799-805.

3. Rezaei Kalantari R, Yari AR, Ahmadi E, et al. Survey of corrosion and scaling potential in drinking water resources of the villages in Qom province by use of four stability indexes (With Quantitative and qualitative analysis. Arch Hyg Sci 2013;2(4): 127-34.

4. Parastoo s, Zinatizade A, Hasani A, sharifpour M. Analysis of the chemical quality of groundwater resources using software Aq.Qa (prairie Songhor village of Kermanshah). 14th Environmental Health Conference: Shahid Sadooghi University of Medical Science; 2011.

5. Mofidi J. Principles of Corrosion and Protection of Metals. 2004.

$$
\begin{aligned}
& \text { رسوب كذار خارج نمود. مهم ترين يارامترهاى كيفى آب كه بر } \\
& \text { مقدار شاخص بوكوريوس اثركـذار هسـتند عبارتنـد از pH و } \\
& \text { سبس كلسيم. به همين منظور مىتوان با تنظيم مقدار كليسم در } \\
& \text { منابع تأمين كننده آب شهرسـتان قـروه وضـعيت آب را ازنظـر } \\
& \text { تمايل به رسوبكذارى يا خورندگى تغيير داد. ايسن نكتـه نيـز } \\
& \text { لازم به ذكر است كه بين شـاخص بوكوريسوس و ميـزان يـون } \\
& \text { كلسيم رابطه معكوسى برقـرار مسىباشــد. در مـورد منـابع آب } \\
& \text { موردمطالعـهـ در ايـنـ تحقيـق بــهمنظـور افـزايش شــاخص } \\
& \text { يوكوريوس و رساندن آن حالت رسوبكذار بهصورت تعادلى لي } \\
& \text { بايد مقدار كلسيم آب كاهش بيدا كند كـه ايسن امـر از طريـت } \\
& \text { سختى زدايى قابل اجرا است. } \\
& \text { نتيجه گيرى }
\end{aligned}
$$

با توجه به يافته هاى اين مطالعه مشخص شد آب محدوده
6. Geldreich EE. Microbial Quality of Water Supply in Distribution Systems: CRC Press; 1996.

7. Ghanizadeh G, Ghaneian M. Corrosion and precipitation potential of drinking-water distribution systems in military centers. J Mil Med 2009;11(3): 155-60.

8. Association AWW. Introduction to Water Treatment: Principles and Practices of Water Supply Operations. American Water Works Association, Denver, Co 1984.

9. Rezaei Kalantary R, Azari A, Ahmadi E, Ahmadi Jebelli M. Quality evaluation and stability index determination of Qom rural drinking water resources. J Health Field 2013;1(3): 9-16 [In persian].

10. Shams M, Mohamadi A, Sajadi SA. Evaluation of corrosion and scaling potential of water in rural water supply distribution networks of Tabas, Iran. World Appl Sci J 2012;17(11): 1484-89.

11. Loewenthal R, Morrison I, Wentzel M. Control of corrosion and aggression in drinking water systems. Water Sci Technol 2004;49(2): 9-18. 
12. Federation WE, Association APH. Standard Methods for The Examination of Water and Wastewater. American Public Health Association (APHA): Washington, DC, USA 2005.

13. Rafferty K. Scaling in geothermal heat pump systems. Prepared for: US Department of Energy, Idaho Operations Office, and 785 DOE Place, Idaho Falls, ID 83401. Contract No DE-FG07-90ID 1999;13040.

14. Chalkeshamiri M. Principles of Water Treatment. 2007.

15. Wagner EG, Pinheiro RG, Organization WH. Upgrading Water Treatment Plants. 2001.

16. Colin M. Stress corrosion cracking: Senior Engineering Consultant Materials Technology. 2008.
17. Iranian Institution for Standards and Economic Research, Physical and Chemical Properties of Drinking Water. Standard Number 1053. 5th edition ed.

18. Pontius FW, Association AWW. Water Quality and Treatment: A Handbook of Community Water Supplies. AWWA; 1990.

19. Hadi M. Preparation of the software calculates eight important corrosive water indexes. 12th National Conference on Environmental Health; Shahid Beheshti University of Medical Science 2009.

20. Poorzamani H, Ghazaie M, Samani A, editors. survey the quality of drinking water source in Esfahan oshtorejan industrial park based on corrosion properties. Environmental Health Congress, Tehran Physician Sciences; 2005. 